\title{
The Impact of B2B Buying Behavior on Customer Satisfaction within SHAHAB KHODRO Company
}

\author{
Rozita Shahbaz Keshvari \\ Sharif University of Technology, IC \\ Kish Island, Iran \\ Tel: 98-912-283-8353 E-mail: Rozita.ShK@GMX.com \\ Elham Faghani \\ SHARIF University of Technology, IC \\ Kish Island, Iran \\ Tel: 98-911-777-3532Ｅ-mail: faghanielham@yahoo.com \\ Abolfazl Memarinia \\ SHARIF University of Technology, IC \\ Kish Island, Iran \\ Tel: 98-915-117-4726_E-mail: abolfazl_memarinia@yahoo.com
}

\author{
Mohamad Ebrahim Rezaei \\ SHARIF University of Technology, IC \\ Kish Island, Iran \\ Tel: 98-912-103-3886Ｅ-mail: moerezaee@yahoo.com
}

\author{
Alireza Miremadi \\ School of Management \\ Sharif University of Technology, International Campus \\ Amir Kabir Square, Kish Island, Iran \\ E-mail: ar.miremadi@sharif.edu
}

Received: January 5, 2012

Accepted: February 2, 2012

Published: April 1, 2012

doi:10.5539/ijbm.v7n7p151

URL: http://dx.doi.org/10.5539/ijbm.v7n7p151

\begin{abstract}
In today's industry, many variables are shown to be important in buying behavior of industrial customers. For reducing the risks associated with purchase decision, process driven team can be an appropriate alternative instead of simple individual buyer. This research has been organized in cooperation with SHAHAB KHODRO, an industrial supplier of Bus (intertwinement, interstate), and Heavy machines. The purpose of this study was to consider how SHAHAB KHODROS' customers discern certain elements (Price, Quality, Service, Relationships, Technical Performance, Technical Knowledge, Time of Delivery, Installation, Flexibility, Market Adjustment, Geographic Distance, Technical Documentation) when choosing it as a supplier of buses and why they perceive them. The study has been conducted employing a combination of both a quantitative and a qualitative approach in which 60 questionnaires has been sent out to SHAHAB KHODROS' customers in order to know their opinions. By this research we can find out if the elements that pervious researcher reached at their relation is
\end{abstract}


correct in our study or not. Definitely, this information and analysis are needed for SHAHAB KHODROS in order to satisfy its customers better by improving their marketing program, and thereby increasing its profitability.

Keywords: DMU, Industrial concept, CRM, Influencer, Decider, Decision making process

\section{Introduction}

As markets become more volatile and complex and competitors more aggressive, it is of great importance to a company to have knowledge about the market that they are working in (R. Deshpandé, 2001). Accordingly, companies that have deep knowledge about their markets has an ability to learn, which makes them better equipped to predict how their markets will respond to actions designed to retain or attract customers or competitors. In industrial marketing concept, because of few numbers of buyers, planning for appropriate marketing strategies which lead to a better customer satisfaction and repurchase decision seems to have a significant role. There are many elements influencing DMU in its decision making process. In Iran industry, it seems that a kind of imbalance in the Importance of these attributes is dominant in buyer's mind. The purpose of this research is to determine this attributes and the importance of each in the decision making process in SHAHAB KHODRO Co. as a representative of the industrial market to create superior customer value through their marketing program. The elements include quality, service, technical performance, technical knowledge, communication, time of delivery, installation, calculation program, flexibility, market adjustment, technical documentation, relationships and geographic distance It is also a way for it to make sure that they keep their current customers satisfied which, in turn, often leads to a stronger and more long lasting business relation.

SHAHAB KHODRO does not have enough knowledge about how the elements in its marketing program influence the customers of its chilled beams and why. This information is needed for it in order to satisfy its customers better by improving their marketing program, and thereby increasing its profitability.

\section{Literature Review}

There are many aspects of marketing. In order to give the reader a broad understanding of the issue, this section presents marketing from a business-to-business perspective and provides in-depth understanding of what factors that influence the business buyer in specific buying situations. Moreover, the $4 \mathrm{P}$ 's are introduced. They are tools that a company uses to carry out its marketing objectives and they will provide a basic structure throughout the research.

\subsection{Business to business in industrial marketing}

In several years ago authors argued that have suppliers for industrial customers means Business-to-business environment. (Singh \& Koshy, 2011). companies that are extremely awareness about their markets are able to learn, which help them better equipped to foretell how their markets will react to actions designed to keep or attract customers or rivals(R Deshpandé, 2001).

\subsection{Value creation in business to business environment}

In business negotiations also Cultural values use to influence the interests, priorities, and strategies (Brett, 2000) that consequently affects an individual's approach for exchange relationships (Shi, 2001).In high context societies it is more implicit that communication between individuals is described by concentrate on non-verbal cues (Cohen, 1991) , and demonstrating trust toward people in different procedure from those in low-context cultures (Hsu, 1983). In this socio-cultural environment, finding the role of value creation in business relationships becomes significant, since value is regarded to be the purpose of cooperative customer-supplier relationships (Anderson, 1995). However research on customer value in business markets is still in an early stage(Flint, Woodruff, \& Gardial, 2002), mainly focusing on the value of the physical product, disregarding to relational dimensions of customer-perceived value(Dwyer \& Tanner, 1999).

Ignoring the salesperson's customer oriented behaviors that may influence the value creation. In spite of a firm's market orientation composed of market sensing, dispersion, and reply, market sensing as a perspective becomes more prominent in which salespersons play a crucial role (Cross, Brashear, Rigdon, \& Bellenger, 2007).

Saxe \& weitz (1982) declare that helping customers make satisfactory purchase decisions is emphasize of customer-oriented selling strategy, while this strategy focuses on making swift sales, often at the expense of long term interests of the customer. We haven't aware until now if b2b salespersons actually create value in their relationship with customers, particularly in the context of emerging markets (Singh \& Koshy, 2011)

The salespersons' customer orientation comprising of selling vs. customer orientation, as practiced with their customers (Singh \& Koshy, 2011). Salespersons are very consequential for creating relationships, and for 
delivering value to b2b customers, particularly the small and medium firms(Singh \& Koshy, 2011) majority of organizational buyers look for expansion of value-added services from salespeople(Liu \& Leach, 2001).

Michel and his colleague's in addition declare that 'dematerialization' of resources permits greater range for value creation. Such a process of value creation requires a salesperson to play a crucial role in the procedure being the central contact person for his/her firm.(Singh \& Koshy, 2011) Homburg and Stock (2004) also indicates that in the b2b selling context, a salesperson is still regarded the key contact point for the customers; $\mathrm{s} / \mathrm{he}$ is also initially responsible to make prosperous relationship with them (Wilson \& Jantrania, 1995).

Furthermore, most organizational buyers look for long-term relationships and higher level of contact from salespeople(Liu \& Leach, 2001) Customer orientation vs. sales oriented approach, includes taking a long-term approach to customers interactions(Franke \& Park, 2006), identical with the relational selling approach(Weitz \& Bradford, 1999) .

\subsection{Sustain relationship with customers by CRM}

Appearing new technologies have made the sales function much more complexes than previous . one way of dealing with the relationship to former customers is the concept of Customer Relations Management (CRM)(Ryding, 2010).“ customer relationship management (CRM) is a combination of people, processes and technology that seeks to understand a company's customers”(Chen \& Popovich, 2003). Several person state that "CRM is a term for methodologies, technologies and ecommerce capabilities used by companies to manage customer relationships.' (Landry, Arnold, \& Arndt, 2005; Ryding, 2010).

Some believes that CRM create as an approach toward sustaining positive relationships with customers, enhance loyalty in customer and improve customer lifetime value(King \& Burgess, 2007). Enhance the knowledge about an approach that customers create their own values is the main goal of CRM-driven company. Therefore, it is easier for company to assess the way of supporting customers based on its competences. The company for achieving to enhance value of customer relations should use more resources on improving former relations than on creating new ones. (Jennie, Elina, \& Linda-Marie, 2005 ) customer value is something that comprehend by customers not by a seller(Jennie, et al., 2005 ) value is based on assessment of product comprehensively after use (Zeithaml, 1988).

B2B marketing (Business -Business) defines as guiding reciprocal relationships among industrial customers and industrial suppliers. The concentrate is on the flow of completed goods and services that are produced or ingredient will become as parts of completed goods and services. The management of these relationships is about deciding whom the organization wishes to have a relationship with, then once having the relationship, how to maintain it. (Morris, Pitt, \& Honeycutt, 2001).

\subsection{Task and non-task variables}

\subsubsection{Task variables}

It is essential for a firm to comprehend its industrial customers by being aware about factors that influences buying preference.(Chisnall, 1989) when industrial buyers make buying decisions they are subject of many affects and they should answer to economic and social factors(Kotler, Armstrong, Saunders, \& Wong, 2002; Morris, et al., 2001) by regarding to economic factors ,particular goods and services that a firm buy directly affect the day-to-day performance and economic health of the company.(Jennie, et al., 2005 ).

One of the factors that highly affect on making buying decision is economic factors and must be taken by pay attention to when disclose the buying behavior of the industrial buyer(Jennie, et al., 2005 ) despite of social and economic factors that affecting in industrial buying behavior there are two other factors that divided to task and non-task variables(Jennie, et al., 2005). Task variables or rational variables influence on purchasing decision such as price, quality, delivery etc, that categorize them into two groups of factors that it include environmental factors and product and market factors. In this condition environmental uncertainty influence purchasing option process with consider to impact on the group of people who gather to make a buying decision(Kauffman, 1996).

Some factors in present and future economic environment such as the initially demands level, the economic perspective and the expense of money strongly influenced industrial purchasers.(Kotler, et al., 2002).Features of product or sorts of products has been distinguished as affecting the industrial purchasing decisions. when purchasing sophisticated products technically, impalpable features such as service are found to be significant than product attributes in the selection process(Kauffman, 1996).

\subsubsection{Non-task variables}

Non-task variables relate to some factors such as organizational, individual and interpersonal factors (Jennie, et 
al., 2005 ).The interpersonal factors involve the purchasing centre or the decision making unit (DMU)(Jennie, et al., 2005 ).

According to Morris et al, in the buying decision based on characters of the purchase, different people from different levels in the organization will be involved. In to the B2B market the mechanism of the DMU is significant(Jennie, et al., 2005 ) DMU involves many different members who influence on each other, and it can be taught to realized what kinds of interpersonal factors and group impact on buying decision(Kotler, et al., 2002). The Decision-making Unit composed of people from different parts of the organization, each of them having some interest in the result of the purchasing efforts such as Users, Influencers, Buyers, Deciders, Gatekeepers (Varey, 2002)

\section{$2.54 p$ 's in industrial marketing}

From a company aspect buying decisions can be influenced by the supplier through a set of marketing tools, called the 4 P's.(Jennie, et al., 2005 ). The 4 P's or marketing program is the collection of marketing tools that a company apply to encourage its marketing objectives that include four marketing tools such as product, price, promotion and place(Cavallaro, 2001).Every business is based on a product or an offer. A company's purpose is create differentiation or change in a better way for their product/offer in order to obtain market preference and eventually increased sales(Jennie, et al., 2005 ).

\subsubsection{Price}

When making decisions about price of the company (Kyambalesa, 2000) regard costs of production, the observation of market the product value and the contest that the company encounters. The product's price does not essentially feedback the cost of producing it, even if cost information is an major outlook of price setting(Kyambalesa, 2000).

There are two kind of price first of all consider "cost based pricing" that indicate base the price on the calculated cost. Another alternative is "value based pricing", where the company appraise the maximum price that a costumer is tend to pay. According to this value consider the price a little lower for purpose of impede customers from hesitating to buy the products.

\subsubsection{Promotion}

In a crystal word promotion is a way of informing, encouraging or reminding customers about the product, price and place(Low \& Tan, 1995)or in the other hand set of activities such as advertising, sales promotion, personal selling, publicity and direct mail that inform the customer about the product and raise consciousness of the product(Miller, 2001).

Selling company require to communicate to its customers for informing them about why they should use one particular company or buy one specific product instead of another(Wright, 2004).generally talking, listening and promoting the company and its brands to customers and markets and trying to creating long-term relationships with customers(Morris, et al., 2001; Wright, 2004)The goals of B2B communication are near to those of mass-market communication. In a brief, it is to make selling in easier way. the purpose is to improve company's reputation and the company's products and expertise, to increase publicity through better identification, to optimize its attraction and eventually to persuade preference and the desire to buy of the target group(Malaval, 2001) . Another significant perspective of promotion is relationship of supplier/buyer. Promoting a company through close relationships create loyalty and repurchases(Jennie, et al., 2005 ). For a firm to promote itself efficiently, it require to make long term-relationships rather than relying on short-term transactions(Kotler, et al., 2002).

\subsubsection{Place}

The another suitable phrase (Miller, 2001).for place is distribution. The distribution of a product can involve wholesalers, retailers, transports and agents (Kyambalesa, 2000).also every supplier should determine how they access products to concerned market(Kotler, 1999)

\subsubsection{Product}

A product is the material, program, or service that is prepared for people and a firm desires to impact (Cavallaro, 2001). A product clarify to something that suggested to a market's attention, utilize or consumption. in addition ,it must satisfied wants or needs of customers(Kotler, et al., 2002). The major goal of company is to provide their product/offer distinctive or better in a way in order to obtain preference of market and therefore increased sales. There are several efficient physical differentiations such as characteristics and performance. In addition characteristics prepare swiftly and credible approaches to display additional advantage. In the other 
hand performance can create a visible differentiation by a product or package(Kotler, 1999). products categorized based on durability and tangibility. First of all non-durable products refer to some products that consumed very fast such as food. The second part include durable products that indicate to some products must consume over period of time for example more than a year's such as cars and furniture(Kotler, et al., 2002).

When a product is developing people in organization who encounter to product planning and development require being awareness about three levels of products such as core product, tangible product and augmented product(Kyambalesa, 2000). Kotler et al.(2002) assumed that a core product include in primary level. It composed of the benefits of problem solving that consumer search to obtain when consumer purchase a product. The tangible product indicates to packaging, styling, features, quality and brand name. Eventually augmentation means sometimes organization suggest extra services and benefits, for example one month guarantee. Furthermore this augmentation can play virtual roll as a completive tool for making product distinct from other one.(Kyambalesa, 2000)

In this part we summarize the literature which is relevant to above discussion. (See Appendix A. Table $\mathrm{A}_{1}$ )

\section{Shahab Khodro}

SHAHAB KHODRO Company with a 43-year history is as one of the largest internal automotive companies that produce urban buses (diesel and gas), special machine between cities (Firefighting machines, Ambulance, Garbage cache ...). Historically, SHAHAB KHODRO Company is known as one of the oldest companies in the Heavy Vehicle manufacturing and assembly of the facility in Iran.

SHAHAB KHODRO supplies buses for intertwinement and interstate terminals, Hydraulic system, Mechanized equipment for garbage transportation, Skip loader, Rotating elbow equipment, Semi Trailer, Firefighting equipment etc. (www.shahabkhodro.com). The ultimate goal of the company is upgrading quality of products. So the system is working on bases of ISO 9000:2000. The certificate for implementation of EFQM model is in process according to long term strategy (www.shahabkhodro.com). The company is producing 1000 buses per year and mix of 500 service vehicles. SHAHAB KHODROS has several customers that are classified in two internal and external groups that Home Office Ministry on behalf of all Bus Terminals and Transportation Organizations is considered as the most important internal customers. More than 30 cities including United Bus Company of Tehran (UBCT) are among our customers. In recent years we have exported to Turkmenistan, Afghanistan, Syria, Armenia, Libya, and Iraq.

The Figure 1 illustrates the relationship between SHAHAB KHODRO and its customers. Three groups of customers that are marked grey in figure are our target customer in this study.

\section{The DMU and the buying decision process}

It is important for a supplier to identify the members of the Decision-making Unit in order to enable a customization of the communication in each single case. The DMU usually consist of members from different parts of an organization. The customers involve consultants and installation engineers and they can be compared to different roles of the DMU, both influencing the buying decision.

The consultant is assigned by the entrepreneur in order to give recommendations to the installation engineer about what product to buy. Thus, the consultant often acts as an influencer affecting the buying decision of the installation engineer. The installation engineer makes the buying decision based on the recommendations from the consultant, thus acting as a decider. It is also the installation engineer who actually purchases the product, thus acting as a buyer.

By relating the DMU roles of the customers to the industrial buying decision process model, it is clear that Company needs to influence different types of customers in different phases of the buying decision process.

Because the consultants often act as influencers defining specifications, and evaluating alternatives, Company needs to affect them in the Product specification phase and to some extent also the Product \& supplier phase of the buying decision process because they influence the evaluation of the most appropriate product. When operating in order to influence the consultants in these phases, the Product and Promotion P's of the marketing program become essential to consider in order to satisfy the consultants' needs because they are affected by what benefits the product have to offer and how Company promote these benefits.

The installation engineers acting as deciders and buyers can be affected to some extent in the Product \& supplier phase and also in the Evaluation of options- and Supplier selection phase of the buying decision process model. They will evaluate and choose the most appropriate supplier and they will make the final decision of what product 
to buy. The installation engineers are affected by all of the 4 P's, and Company therefore needs to put a lot of effort into highlighting their benefits of these P's compared to their competitors. (See Figure 2)

\section{Methodology}

The purpose and research objectives of this research indicate that this study is descriptive and for quantifying the data and generalize the results from the sample to the population of interest, quantitative approach is appropriate choice for us. There are different types of strategies that are available to choose for conducting the research. Regard to obtain practical results and answer to our research question that was based on "what (which)" question, we conducted comprehensive survey.

After a research problem is defined, this is the turn to collect data. Due to the aim of this study was to get business customers' view, the best method to collect information was distributing questionnaire and communicate with them face to face. It comprised 12, 5-likert questions comprised the elements extracted from the literature, a question of ranking the elements and a simple question which leads to NPS (Net Promoter Score) (Appendix B: Sample of Questioner).

The questionnaire was distributed among 60 members of the organizations, involved in DMU. Actually these organizations were the customers of SHAHAB KHODRO, like BEYHAGHI terminal, ROYALSAFAR, IRANPEYMA companies in West terminal and South terminals, ADL and ARASH companies, MASHHAD terminals and the internal terminal buses in different regions of Tehran like: ONE and FIVE. Our study's finding analysis are done by SPSS, and also Microsoft Excel to find out the most important elements today are the same as they were before, or other elements have acquired a more central role.

\section{Empirical findings}

\subsection{Quantitative Analysis}

The result mentioned bellow is based on sixty answers of sixty questionnaires which were distributed to SHAHAB KHODRO customers. The results will be structured according to the 4P's and the answer of fixed questions will be referred in the following way:
1: Strongly Disagree,
2: Disagree
3: Undecided,
4: Agree,
5: Strongly Agree

\subsubsection{Reliability}

Reliability pertains to a measure whereby similar results are generated overtime and situations. It is a degree to which measures are free from errors by giving up consistent results. It is a necessary condition for validity (Zikmund, 2000). Measuring Cronbach's Alpha is a suitable way to estimate the internal consistency. In this study the Cronbach's Alpha is 0.83 which refer to a high level of reliability. (See Table 1)

\subsubsection{Product}

On the first question about how the buses' services are satisfying when calling SHAHAB KHODRO's vendors or technical support, 50.0 percent were disagree that the services of this company were satisfied due to lack of sufficient representatives in all over the Iran. 41.7 percent of the customers were generally satisfied with these services and very few of the respondents answered Undecided (See Table 2).

The next question is about how satisfying SHAHAB KHODRO's Technical performance, 45.0 percent of the customers answered that they were agree with the technical performance. An amount of 37.4 percent was disagree and not satisfied, as shown in Table 3. The customers imply different reasons for their dissatisfaction of SHAHAB KHODRO's Technical performance such as: making crazy sounds and weak internal design (for instance bad position of refrigerator in bus)

Regarding how satisfying the Technical knowledge of the employees at SHAHAB KHODRO is, above 45.0 percent were Agree and Strongly Agree according to this fact that the people in SHAHAB KHODRO that they had been in contact with have enough technical knowledge, responsibility and 30.0 percent chose undecided, because they think SHAHAB KHODRO's location in comparison with other competitors (IRAN KHODRO, VOLVO, OGHAB, VIP...) is in middle infield of Technical knowledge. (Table 4)

On the question about how easy the installations of the buses are, 28.3 percent of customers chose Undecided due to lack of enough knowledge about the buses' installation, and they are final buyer who purchase the final installed buses. The overall satisfied customers' percentages were 48.4. (See Table 5)

The question about SHAHAB KHODRO's flexibility had wide spread answers, 35.0 percent answered that they were strongly disagree that it was flexible in terms of customer support, spare parts. As see in Table 6 about 15.0 percent are also answered Disagree, so 50.0 percent were generally dissatisfied about the flexibility because this 
company didn't pay attention enough to customers' need. Approximately, 31.3 percent were satisfied. The reason why some of customers were satisfied cheap and available spare parts, customer support.

In the area of technical documentation, most of the customers agreed that SHAHAB KHODRO has a clear and easily used technical documentation (45.0 percent). The customers' motivation was they can easily find the SHAHAB KHODRO's buses list by contacting with knowledgeable staff. They mentioned that whenever they wanted to purchase the bus, all of documentation (Model, Price...) are clarified and obvious. On the other hand, about 26.7 percent believe that knowing about the Technical documentation is referred to the Transportation Organizations, because they bought the buses and employed the driver (beneficiary) to use them. (See Table 7)

\subsubsection{Price}

According to the question about SHAHAB KHODRO's price in the sense of performance, 70 percent were satisfied with the price of buses. Most of the customers implied that low price of buses is one of the most important factor that motivated them to purchase the buses. Moreover, 23.3 percent of customers believed that the price of buses in comparison with its competitors had middle price. (Shown in Table 8)

\subsubsection{Promotion}

Regarding to the question whether customers have Clear and Satisfying Communication with SHAHAB KHODRO's employees, the answers shown that 48.3 percent of customers were not pleased. As shown in table 9, 36.7 percent were satisfied about their communication with SHAHAB KHODRO's employees. The pleased customers said that when they communicate with staff and need their help, the SHAHAB KHODRO's employees are pleasant and conduct them with good services. (Table 9)

On the question about SHAHAB KHODRO's marketing activities in introducing its buses, more than half of the customers did not agree that SHAHAB KHODRO is worked well enough in its marketing program (see table 10). Dissatisfied customers mentioned that due to poor marketing activities of this company, mostly no one didn't become aware of the new buses' model, the services, the price and etc. About 21.7 percent of the customers were satisfied and the rest said its marketing program is in average place. (Shown in Table 10)

The customers were also asked if a good earlier relation with a supplier increases the probability of future cooperation. As can be seen in Figure 3, 53 customers ( 85.0 percent) were agreed because they knew that one of the influential factors in cooperation continuous is good relationship with supplier. The few amounts of customers about 8.3 percent were not satisfied.

\subsubsection{Place}

The customers were asked the question about their satisfaction on Geographical distance to SHAHAB KHODRO's vendors. 40.0 percent of them answered that their distance was good and they were satisfied, because most of their companies were closed to SHAHAB KHODRO Company. As can see in Table 11, the percentage of customers who were dissatisfied is 31.6 percent that most of them were unpleased about lack of representatives of SHAHAB KHODRO.

According to the question about how reasonable the Time of delivery of SHAHAB KHODRO's buses is, 43.4 percent of the customer agreed that the Time delivery of buses is good and satisfying. On the other hand, 36.7 percent were compared with other bus companies, and 20.0 percent believed that SHAHAB KHODRO's Time of buses delivery is in middle. (See Table 12)

\subsubsection{The ranking of the elements}

For ranking of the elements by the customers, we used Friedman Test that determined five most significant ones influencing the customers' buying behavior respectively: Marketing of SHAHAB KHODRO for introducing buses, Flexibility of SHAHAB KHODRO in sense of customer support, Clear and Satisfying communication with people, Geographical distance to SHAHAB KHODRO's vendors and Clear and easy Technical Decimations. (See figure 6.2, the less mean rank elements are the most important ones in Friedman test). So we can suggest to SHAHAB KHODRO to focus for better performance. The three least important ones are respectively: An earlier relation with a supplier increase the profitability of future cooperation, Price of SHAHAB KHODRO's buses compared with performance and Technical Knowledge of staff that are explanatory of this fact that SHAHAB KHODRO are worked well in these fields and its customers were satisfied.

Moreover, by doing Friedman test; we test our hypotheses that are mentioned below:

1) All the elements have the same importance in comparison with each other. (H0)

This hypothesis is rejected (Asymp. Sig. $=0.000<0.05$ ), so at least one element as more importance than others. 
(Table 13)

2) Price and relationship are fundamental factors in buying behavior of customer in Iran.

3) Implementing CRM has influenced buying behavior of Iran Industries.

4) Customers easily access to representative (place) and promotion (as $4 p$ factors) are not well served in Iran industries.

The rest of hypotheses are all accepted according to the Mean rank is shown in figure 6.2.

\subsubsection{Correlation between elements}

Correlation analysis of SPSS shows the relation between attributes and their correlativity in terms of each other. Correlation number fluctuates between -1 and 1 . If the amount of correlation between two attributes tends to one, it shows the high correlation of those attributes. For example the correlation between "after sale services" and "clear and satisfying communication with customer" is 0.747 which as we know for after sale service, the communication with customer in extremely important and it should be clear and satisfying. So this amount of correlation (.747) confirms this issue about after sale services.

Or the correlation between "after sale services" and "flexibility of customer support" is 0.672 . Again it shows that in offering after sale services the flexibility in support is important and company may sometimes prefer to do some modifications in services in order improve customer satisfaction. ( Shown in Table 14)

\subsubsection{NPS (Net Promoter Score)}

How likely is it that you would recommend SHAHAB KHODRO to a friend or colleague?

NPS is based on the fundamental perspective that every company's customers can be divided into three categories:

- $\quad$ Promoters (score 9-10) are loyal enthusiasts who will keep buying and refer others, fueling growth.

- Passives (score 7-8) are satisfied but unenthusiastic customers who are vulnerable to competitive offerings.

- Detractors (score 0-6) are unhappy customers who can damage your brand and impede growth through negative word-of-mouth.

In order to determine the NPS for SHAHAB KHODRO we distributed 60 questionnaires between buyers of SHAHAB KHODRO. 42 of buyers were detractors, 11 of them were passives and 7 rest buyers were promoters.

To calculate SHAHAB KHODRO'S Net Promoter Score (NPS), should take the percentage of customers who are Promoters and subtract the percentage who are Detractors:

NPS $=\%$ of Promoters $-\%$ of Detractors

6.2 Qualitative Analysis

Result: NPS $=\mathbf{- 5 8} \%$

6.2.1 The customer' viewpoint about the most influential elements in choosing SHAHAB KHODRO

In this question, we asked customer to rank the most influential elements in choosing SHAHAB KHODRO Company as a supplier of bus. As shown in following table, Services has the highest score (62) in comparison with other elements in customers' opinion that is considered as the number 1 important element. The next high score (46) is referred to Technical knowledge as number $\underline{2}$, and the third one is Technical documentation with score of 33 . Respectively, Services, Technical knowledge and Technical documentation are three most important elements by customers when choosing SHAHAB KHODRO.

The elements mentioned above are confirmed by the result of Friedman test, where the highest rank is assigned to these attributes. The two most mean rank belong to Price and Relation which are approved by the interview from the respondents. (Table 15)

\subsubsection{The Deciders}

Regarding to our next qualitative question about who are the decision makers in customers' company, 48.57 percent of customers mentioned that the Bus's owner and the head of company are the final decision makers. 22.56 percent mentioned that the Bus's owner are the only decider due to this fact that bus's owner often have technical knowledge and also they purchase themselves so we can consider them as persons who involved in all parts of DMU. The rest of them as indicated in following table, said buses' partner, Traffic Organization and Executive Manger of company's opinions affected the buying decision making. Eventually, Bus's owner and the head of company are two persons who decide. (See Table 16) 


\section{Conclusion}

In a brief conclusion, this research is run to determine how Iranian industrial buyers perceive several elements when choosing their supplier.

Overall the result from the survey of this study on SHAHAB KHODRO Co. showed that most of this company's consumers are dissatisfied with their supplier. Low price and Relation are the most important factor persuading the buyer to purchase from this company. According to Friedman test resulted from SPSS they should work more on some features namely, technical performance, flexibility and ....

It seems that the role of price and relation can be extended to entire industrial environment of Iran. Therefore most domestic producer is selling their product in internal market while they cannot send them out of the borders due to lack of desired performance.

\section{Limitation}

There is a risk that some of the questions given in the questionnaire in this study may have been misunderstood and misinterpreted. The questionnaire in this study included terms such as communication, geographical distance and relationships. These terms are examples of words that often have different meanings to different people. These words are extracted from professional context but they may have other explanation in respondent's mind. Maybe more description about few questions could be helpful.

Worth mentioning is also that unfortunately like most other studies, some of the respondent were not enough sophisticated to be precise in answering the questions. Therefore some part of the data could be more exact.

\section{Further studies}

The authors believe that there can be much more researches in this area because of getting the industry more competitive and the market more expanded and turbulent. Each industry may have its own characteristic, so can be influenced in a different way. Further effort can be placed on more industries covered by the research.

Even this study can be more completed through gaining more SHAHAB KHODRO's customer's responds. Also other products of this company can be included.

The elements intended to be measured are all extract from the literature have been done before. Culture of purchase, the Decision making process and also DMU can be somehow different in Iran's industry landscape. Further studies can involve more the elements influencing the buying decision of specially IRANIAN industries .Maybe more elements are discovered which were not so significant in global point of view.

\section{References}

Anderson, J. C. (1995). Relationships in business markets. Journal of the Academy of Marketing Science, 346-350.

Brett, J. (2000). Culture and Negotiation. International Journal of Psychology, 35, 97-104. http://dx.doi.org/10.1080/002075900399385

Cavallaro, M. A. (2001). Marketing risk management. Risk Management, 46-50.

Chen, J. I., \& Popovich, K. (2003). Understanding customer relationship management. Business Process Management Journal, Vol. 9 Iss: 5, pp.672 - 688. http://dx.doi.org/10.1108/14637150310496758

Chisnall, P. M. (1989). Strategic Industrial Marketing. Hemel Hempstead: Prentice Hall.

Cohen, R. (1991). Negotiating across cultures. United States. Institute of Peace Press. Washington, D.C.

Cross, M. E., Brashear, T. G., Rigdon, E. E., \& Bellenger, D. N. (2007). Customer orientation and salesperson performance. European Journal of Marketing, Vol. 41 Iss: $7 / 8$, pp.821 $\quad$ - 835 . http://dx.doi.org/10.1108/03090560710752410

Czepiel, J. A., \& Rosenberg, L. J. (1992). A marketing approach for customer retention. The Journal of Product and Brand Management. Vol. 1 Iss: 1, pp.27-33.

Deshpandé, R. (2001). Using market knowledge. Sage Publications.

Dwyer, F. R., \& Tanner, J. F., Jr. (1999). Business marketing: Connecting strategy, relationships and learning. McGraw-Hill/Irwin.

Flint, D. J., Woodruff, R. B., \& Gardial, S. F. (2002). Exploring the phenomenon of customers' desired value change in a business-to-business context. Journal of Marketin, 102-117.

Franke, G. R., \& Park, J. E. (2006). Salesperson adaptive selling behavior and customer orientation. Journal of 
Marketing Research, 693-702. http://dx.doi.org/10.1509/jmkr.43.4.693

Hsu, F. L. K. (1983). Rugged individualism reconsidere. University of Tennessee Press.

Jennie, B., Elina, L., \& Linda-Marie, W. (2005 ). What Influences B2B Buying Behaviour?: An empirical study of Fläkt Woods and its customers. Bachelor's Thesis in Marketing.

Kauffman, R. G. (1996). Influences on organisational buying choice processes. The Journal of Business \& Industrial Marketing, Vol. 11 Iss: 3/4, pp.94 - 107. http://dx.doi.org/10.1108/08858629610125496

King, F. S., \& Burgess, F. T. (2007). Understanding success and failure in customer relationship management. Industrial Marketing Management, 37: 421-431. http://dx.doi.org/10.1016/j.indmarman.2007.02.005

Kotler, P., Armstrong, G., Saunders, J., \& Wong, V. (2002). Principles of Marketing (9th Edition.). New York: Prentice Hall.

Kyambalesa, H. (2000). Marketing in the 21st Century.

Landry, T., Arnold, J. T., \& Arndt, A. (2005). A compendium of sales related literature in customer relationship management: processes and technologies with managerial implications. Journal of Personal Selling and Sales Management, 25 (3), 231-251.

Lin, C. (2003). A critical appraisal of customer satisfaction and e-commerce. Managerial Auditing Journal, Vol.18. No.3. 9. http://dx.doi.org/10.1108/02686900310469952

Liu, A. H., \& Leach, M. P. (2001). Developing loyal customers with a value-adding salesforce: Examining customer satisfaction and the perceived credibility of consultative salespeople. Journal of Personal Selling \& Sales Management, Vol.21 No.2 pp147-156.

Low, S. P., \& Tan, M. C. S. (1995). A convergence of Western marketing mix concepts and oriental strategic thinking. Marketing Intelligence \& Planning, 36-46. http://dx.doi.org/10.1108/02634509510083491

Malaval, P. (2001). Strategy and Management of Industrial Brands. Kluwer academic publishers. http://dx.doi.org/10.1007/978-1-4615-1737-5

Marcel Paulssen, \& Birk, M. M. (2007). Satisfaction and repurchase behavior in a business-to-business setting: Investigating the moderating effect of manufacturer, company and demographic characteristics. Industrial Marketing Management, 983-997.

Miller, O. (2001). The product life cycle \& the marketing mix. Credit Management, 36-38.

Morris, M. H., Pitt, L. F., \& Honeycutt, E. D. (2001). Business-to-Business Marketing: A Strategic Approach. Thousand Oaks, CA: Sage Publishing.

Park, H. C., \& Kim, G. Y. (2003). A framework of dynamic CRM: linking marketing with information strategy. Business Process Management Journal, 9(5),. 652-671. http://dx.doi.org/10.1108/14637150310496749

Parker, C., \& Mathews, B. P. (2001). Customer satisfaction. Marketing Intelligence \& Planning, Vol. 19 Iss: 1, pp.38 - 44. http://dx.doi.org/10.1108/02634500110363790

Reichheld, F. F. (1996). Learning from customer defections. Harvard Business Review, Vol. 9 Iss: 5, pp.652 671.

Ryding, D. (2010). The impact of new technologies on customer satisfaction and business to business customer relationships: Evidence from the soft drinks industry. Journal of Retailing and Consumer Services, 224-228. http://dx.doi.org/10.1016/j.jretconser.2010.03.008

Saxe, R., \& Weitz, B. A. (1982). The SOCO Scale: A measure of the customer orientation of salespeople. Journal of Marketing Research, Vol. XIX, 343-51. http://dx.doi.org/10.2307/3151568

Shi, X. (2001). Antecedent factors of international business negotiations in the China context. Management International Review, 41 (2), 163-187.

Singh, R., \& Koshy, A. (2011). Does salesperson's customer orientation create value in B2B relationships? Empirical evidence from India. Industrial Marketing Management, 78-85. http://dx.doi.org/10.1016/j.indmarman.2010.09.012

Smith, P. R., \& Taylor, J. (2002). Marketing Communications: An Integrated Approach. (3rd ed). London: Kogan Page.

Varey, R. (2002). Marketing Communication: Principles and practice, London. New York: Routledge. 
Weitz, B. A., \& Bradford, K. D. (1999). Personal selling and sales management: A relationship marketing perspective. Journal of the Academy of Marketing Science, 27 (2), 241-254. http://dx.doi.org/10.1177/0092070399272008

Wilson, D. T., \& Jantrania, S. (1995). Understanding the value of a relationship. Asia Australia Marketing Journal,.2(1): 55-66. http://dx.doi.org/10.1016/S1320-1646(94)70278-1

Wright, R. (2004). Business-to-Business Marketing: A step-by-step guide. London, England, United Kingdom: Financial Times Pearson Education.

Zeithaml, V. A. (1988). Consumer perceptions of price, quality, and value. Journal of Marketing Research, 52(3): $2-22$.

http://www.marketingprofs.com/charts/2011/4549/youtube-tops-facebook-twitter-in-user-satisfaction

Table 1. Reliability Statistics

\begin{tabular}{|c|c|}
\hline Cranach's Alpha & N of Items \\
\hline .838 & 12 \\
\hline
\end{tabular}

Table 2. After sale services of SHAHAB KHODRO's buses

\begin{tabular}{|l|l|c|c|c|c|}
\hline \multicolumn{2}{|l|}{ Services } & Frequency & Percent & $\begin{array}{c}\text { Valid } \\
\text { Percent }\end{array}$ & $\begin{array}{c}\text { Cumulative } \\
\text { Percent }\end{array}$ \\
\hline \multirow{4}{*}{ Valid } & Strongly Disagree & 22 & 36.7 & 36.7 & 36.7 \\
\cline { 2 - 6 } & Disagree & 8 & 13.3 & 13.3 & 50.0 \\
\cline { 2 - 6 } & Undecided & 5 & 8.3 & 8.3 & 58.3 \\
\cline { 2 - 6 } & Agree & 7 & 11.7 & 11.7 & 70.0 \\
\cline { 2 - 6 } & Strongly Agree & 18 & 30.0 & 30.0 & 100.0 \\
\cline { 2 - 6 } & Total & 60 & 100.0 & 100.0 & \\
\hline
\end{tabular}

Table 3. Technical Performance of SHAHABKHODRO buses

\begin{tabular}{|l|l|c|c|c|c|}
\hline \multicolumn{2}{|l|}{ Technical Performance } & Frequency & Percent & $\begin{array}{c}\text { Valid } \\
\text { Percent }\end{array}$ & $\begin{array}{c}\text { Cumulative } \\
\text { Percent }\end{array}$ \\
\hline \multirow{4}{*}{ Valid } & Strongly Disagree & 10 & 16.7 & 16.7 & 16.7 \\
\cline { 2 - 6 } & Disagree & 13 & 21.7 & 21.7 & 38.3 \\
\cline { 2 - 6 } & Undecided & 10 & 16.7 & 16.7 & 55.0 \\
\cline { 2 - 6 } & Agree & 18 & 30.0 & 30.0 & 85.0 \\
\cline { 2 - 6 } & Strongly Agree & 9 & 15.0 & 15.0 & 100.0 \\
\cline { 2 - 6 } & Total & 60 & 100.0 & 100.0 & \\
\hline
\end{tabular}

Table 4. Technical Knowledge of staff

\begin{tabular}{|l|l|c|c|c|c|}
\hline \multicolumn{2}{|l|}{ Technical knowledge } & Frequency & Percent & $\begin{array}{c}\text { Valid } \\
\text { Percent }\end{array}$ & $\begin{array}{c}\text { Cumulative } \\
\text { Percent }\end{array}$ \\
\hline \multirow{7}{*}{ Valid } & Strongly Disagree & 5 & 8.3 & 8.3 & 8.3 \\
\cline { 2 - 6 } & Disagree & 10 & 16.7 & 16.7 & 25.0 \\
\cline { 2 - 6 } & Undecided & 18 & 30.0 & 30.0 & 55.0 \\
\cline { 2 - 6 } & Agree & 14 & 23.3 & 23.3 & 78.3 \\
\cline { 2 - 6 } & Strongly Agree & 13 & 21.7 & 21.7 & 100.0 \\
\cline { 2 - 6 } & Total & 60 & 100.0 & 100.0 & \\
\hline
\end{tabular}


Table 5. Easy Installation of buses

\begin{tabular}{|l|l|c|c|c|c|}
\hline \multicolumn{2}{|l|}{ Installation } & Frequency & Percent & $\begin{array}{c}\text { Valid } \\
\text { Percent }\end{array}$ & $\begin{array}{c}\text { Cumulative } \\
\text { Percent }\end{array}$ \\
\hline \multirow{5}{*}{ Valid } & Strongly Disagree & 7 & 11.7 & 11.7 & 11.7 \\
\cline { 2 - 6 } & Disagree & 7 & 11.7 & 11.7 & 23.3 \\
\cline { 2 - 5 } & Undecided & 17 & 28.3 & 28.3 & 51.7 \\
\cline { 2 - 5 } & Agree & 16 & 26.7 & 26.7 & 78.3 \\
\cline { 2 - 6 } & Strongly Agree & 13 & 21.7 & 21.7 & 100.0 \\
\cline { 2 - 6 } & Total & 60 & 100.0 & 100.0 & \\
\hline
\end{tabular}

Table 6. Flexibility of SHAHAB KHODRO in sense of customer support, spare parts

\begin{tabular}{|l|l|c|c|c|c|}
\hline \multicolumn{2}{|l|}{ Flexibility } & Frequency & Percent & $\begin{array}{c}\text { Valid } \\
\text { Percent }\end{array}$ & $\begin{array}{c}\text { Cumulative } \\
\text { Percent }\end{array}$ \\
\hline \multirow{5}{*}{ Valid } & Strongly Disagree & 21 & 35.0 & 35.0 & 35.0 \\
\cline { 2 - 6 } & Disagree & 9 & 15.0 & 15.0 & 50.0 \\
\cline { 2 - 6 } & Undecided & 11 & 18.3 & 18.3 & 68.3 \\
\cline { 2 - 6 } & Agree & 14 & 23.3 & 23.3 & 91.7 \\
\cline { 2 - 6 } & Strongly Agree & 5 & 8.3 & 8.3 & 100.0 \\
\cline { 2 - 6 } & Total & 60 & 100.0 & 100.0 & \\
\hline
\end{tabular}

Table 7. Clear and easy Technical Documentation

\begin{tabular}{|l|l|c|c|c|c|}
\hline \multicolumn{2}{|l|}{ Technical Documentation } & Frequency & Percent & $\begin{array}{c}\text { Valid } \\
\text { Percent }\end{array}$ & $\begin{array}{c}\text { Cumulative } \\
\text { Percent }\end{array}$ \\
\hline \multirow{5}{*}{ Valid } & Strongly Disagree & 11 & 18.3 & 18.3 & 18.3 \\
\cline { 2 - 6 } & Disagree & 6 & 10.0 & 10.0 & 28.3 \\
\cline { 2 - 5 } & Undecided & 16 & 26.7 & 26.7 & 55.0 \\
\cline { 2 - 5 } & Agree & 16 & 26.7 & 26.7 & 81.7 \\
\cline { 2 - 6 } & Strongly Agree & 11 & 18.3 & 18.3 & 100.0 \\
\cline { 2 - 6 } & Total & 60 & 100.0 & 100.0 & \\
\hline
\end{tabular}

Table 8. Price of SHAHAB KHODRO's buses compared with performance

\begin{tabular}{|l|l|c|c|c|c|}
\hline \multicolumn{2}{|l|}{ Price } & Frequency & Percent & $\begin{array}{c}\text { Valid } \\
\text { Percent }\end{array}$ & $\begin{array}{c}\text { Cumulative } \\
\text { Percent }\end{array}$ \\
\hline \multirow{5}{*}{ Valid } & Strongly Disagree & 1 & 1.7 & 1.7 & 1.7 \\
\cline { 2 - 6 } & Disagree & 3 & 5.0 & 5.0 & 6.7 \\
\cline { 2 - 6 } & Undecided & 14 & 23.3 & 23.3 & 30.0 \\
\cline { 2 - 6 } & Agree & 22 & 36.7 & 36.7 & 66.7 \\
\cline { 2 - 6 } & Strongly Agree & 20 & 33.3 & 33.3 & 100.0 \\
\cline { 2 - 6 } & Total & 60 & 100.0 & 100.0 & \\
\hline
\end{tabular}

Table 9. Clear and Satisfying communication with people

\begin{tabular}{|l|l|c|c|c|c|}
\hline \multicolumn{2}{|l|}{ Satisfying communication } & Frequency & Percent & $\begin{array}{c}\text { Valid } \\
\text { Percent }\end{array}$ & $\begin{array}{c}\text { Cumulative } \\
\text { Percent }\end{array}$ \\
\hline \multirow{5}{*}{ Valid } & Strongly Disagree & 15 & 25.0 & 25.0 & 25.0 \\
\cline { 2 - 6 } & Disagree & 14 & 23.3 & 23.3 & 48.3 \\
\cline { 2 - 6 } & Undecided & 9 & 15.0 & 15.0 & 63.3 \\
\cline { 2 - 6 } & Agree & 15 & 25.0 & 25.0 & 88.3 \\
\cline { 2 - 6 } & Strongly Agree & 7 & 11.7 & 11.7 & 100.0 \\
\cline { 2 - 6 } & Total & 60 & 100.0 & 100.0 & \\
\hline
\end{tabular}


Table 10. Marketing of SHAHAB KHODRO for introducing buses

\begin{tabular}{|l|l|c|c|c|c|}
\hline \multicolumn{2}{|l|}{ Marketing } & Frequency & Percent & $\begin{array}{c}\text { Valid } \\
\text { Percent }\end{array}$ & $\begin{array}{c}\text { Cumulative } \\
\text { Percent }\end{array}$ \\
\hline \multirow{5}{*}{ Valid } & Strongly Disagree & 27 & 45.0 & 45.0 & 45.0 \\
\cline { 2 - 6 } & Disagree & 9 & 15.0 & 15.0 & 60.0 \\
\cline { 2 - 6 } & Undecided & 11 & 18.3 & 18.3 & 78.3 \\
\cline { 2 - 6 } & Agree & 10 & 16.7 & 16.7 & 95.0 \\
\cline { 2 - 6 } & Strongly Agree & 3 & 5.0 & 5.0 & 100.0 \\
\cline { 2 - 6 } & Total & 60 & 100.0 & 100.0 & \\
\hline
\end{tabular}

Table 11. Geographical distance to SHAHAB KHODRO's vendors

\begin{tabular}{|l|l|c|c|c|c|}
\hline \multicolumn{2}{|l|}{ Geographical distance } & Frequency & Percent & $\begin{array}{c}\text { Valid } \\
\text { Percent }\end{array}$ & $\begin{array}{c}\text { Cumulative } \\
\text { Percent }\end{array}$ \\
\hline \multirow{4}{*}{ Valid } & Strongly Disagree & 11 & 18.3 & 18.3 & 18.3 \\
\cline { 2 - 6 } & Disagree & 8 & 13.3 & 13.3 & 31.7 \\
\cline { 2 - 6 } & Undecided & 17 & 28.3 & 28.3 & 60.0 \\
\cline { 2 - 6 } & Agree & 11 & 18.3 & 18.3 & 78.3 \\
\cline { 2 - 6 } & Strongly Agree & 13 & 21.7 & 21.7 & 100.0 \\
\cline { 2 - 6 } & Total & 60 & 100.0 & 100.0 & \\
\hline
\end{tabular}

Table 12. Time Delivery of SHAHAB KHODRO's buses

\begin{tabular}{|c|l|c|c|c|c|}
\hline \multicolumn{2}{|l|}{ Time Delivery } & Frequency & Percent & $\begin{array}{c}\text { Valid } \\
\text { Percent }\end{array}$ & $\begin{array}{c}\text { Cumulative } \\
\text { Percent }\end{array}$ \\
\hline \multirow{5}{*}{ Valid } & Strongly Disagree & 9 & 15.0 & 15.0 & 15.0 \\
\cline { 2 - 6 } & Disagree & 13 & 21.7 & 21.7 & 36.7 \\
\cline { 2 - 6 } & Undecided & 12 & 20.0 & 20.0 & 56.7 \\
\cline { 2 - 6 } & Agree & 16 & 26.7 & 26.7 & 83.3 \\
\cline { 2 - 6 } & Strongly Agree & 10 & 16.7 & 16.7 & 100.0 \\
\cline { 2 - 6 } & Total & 60 & 100.0 & 100.0 & \\
\hline
\end{tabular}

Table 13. Test Statistics; Friedman Test

\begin{tabular}{|l|r|}
\hline $\mathbf{N}$ & 60 \\
\hline Chi-square & 135.732 \\
\hline df & 11 \\
\hline Asymp. Sig. & .000 \\
\hline
\end{tabular}


Table 14. Correlation between elements

\begin{tabular}{|c|c|c|c|c|c|c|c|c|c|c|c|c|c|}
\hline & & 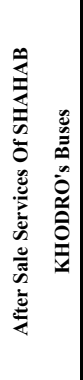 & 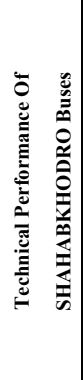 & 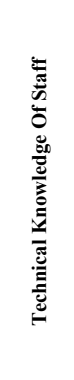 & 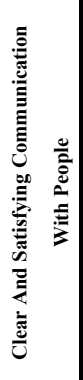 & 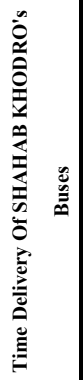 & 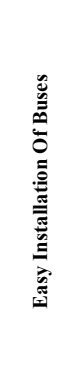 & 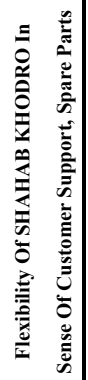 & 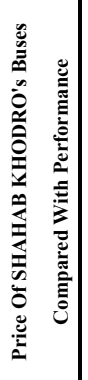 & 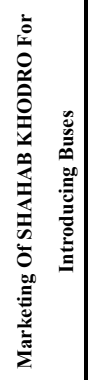 & 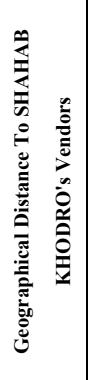 & 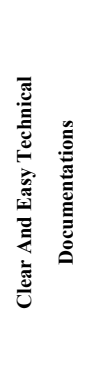 & 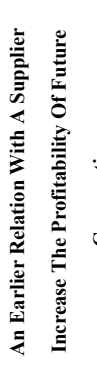 \\
\hline & $\begin{array}{l}\text { Pearson Correlation } \\
\text { Sig. (2-tailed) } \\
\mathrm{N}\end{array}$ & 60 & $\begin{array}{l}.701^{* *} \\
.000 \\
60 \\
\end{array}$ & $\begin{array}{l}.418^{* *} \\
.001 \\
60 \\
\end{array}$ & $\begin{array}{l}.747^{* * *} \\
.000 \\
60 \\
\end{array}$ & $\begin{array}{l}.102 \\
.438 \\
60 \\
\end{array}$ & $\begin{array}{l}.443^{* *} \\
.000 \\
60 \\
\end{array}$ & $\begin{array}{l}.672^{* *} \\
.000 \\
60 \\
\end{array}$ & $\begin{array}{c}-.056 \\
.672 \\
60 \\
\end{array}$ & $\begin{array}{l}.585^{* *} \\
.000 \\
60 \\
\end{array}$ & $\begin{array}{l}.107 \\
.416 \\
60 \\
\end{array}$ & $\begin{array}{l}.142 \\
.279 \\
60 \\
\end{array}$ & $\begin{array}{c}-.157 \\
.232 \\
60 \\
\end{array}$ \\
\hline $\begin{array}{l}\text { Technical Performance Of } \\
\text { SHAHABKHODRO Buses }\end{array}$ & $\begin{array}{l}\text { Pearson Correlation } \\
\text { Sig. (2-tailed) } \\
\mathrm{N}\end{array}$ & $\begin{array}{c}.701^{* *} \\
.000 \\
60 \\
\end{array}$ & 60 & $\begin{array}{c}.164 \\
.211 \\
60 \\
\end{array}$ & $\begin{array}{c}.625^{* *} \\
.000 \\
60 \\
\end{array}$ & $\begin{array}{l}.035 \\
.788 \\
60 \\
\end{array}$ & $\begin{array}{l}.118 \\
.368 \\
60 \\
\end{array}$ & $\begin{array}{c}.445^{* *} \\
.000 \\
60 \\
\end{array}$ & $\begin{array}{l}.067 \\
.610 \\
60 \\
\end{array}$ & $\begin{array}{l}.501^{* *} \\
.000 \\
60 \\
\end{array}$ & $\begin{array}{c}.033 \\
.802 \\
60 \\
\end{array}$ & $\begin{array}{c}-.060 \\
.647 \\
60 \\
\end{array}$ & $\begin{array}{c}-.147 \\
.263 \\
60 \\
\end{array}$ \\
\hline Technical Knowledge Of Staff & $\begin{array}{l}\text { Pearson Correlation } \\
\text { Sig. (2-tailed) } \\
\text { N }\end{array}$ & $\begin{array}{l}.418^{* *} \\
.001 \\
60\end{array}$ & $\begin{array}{l}.164 \\
.211 \\
60 \\
\end{array}$ & 60 & $\begin{array}{l}.408^{* * *} \\
.001 \\
60\end{array}$ & $\begin{array}{l}.438^{* *} \\
.000 \\
60\end{array}$ & $\begin{array}{l}.541^{* *} \\
.000 \\
60\end{array}$ & $\begin{array}{l}.484^{* *} \\
.000 \\
60 \\
\end{array}$ & $\begin{array}{c}.314^{*} \\
.014 \\
60 \\
\end{array}$ & $\begin{array}{l}.394^{* *} \\
.002 \\
60 \\
\end{array}$ & $\begin{array}{l}.284^{*} \\
.028 \\
60 \\
\end{array}$ & $\begin{array}{c}.627^{* *} \\
.000 \\
60\end{array}$ & $\begin{array}{l}.189 \\
.147 \\
60\end{array}$ \\
\hline $\begin{array}{l}\text { Clear And Satisfying } \\
\text { Communication With People }\end{array}$ & $\begin{array}{l}\text { Pearson Correlation } \\
\text { Sig. (2-tailed) } \\
\mathrm{N}\end{array}$ & $\begin{array}{c}.747^{* *} \\
.000 \\
60 \\
\end{array}$ & $\begin{array}{c}.625^{* *} \\
.000 \\
60 \\
\end{array}$ & $\begin{array}{c}.408^{* *} \\
.001 \\
60 \\
\end{array}$ & 60 & $\begin{array}{l}.195 \\
.135 \\
60 \\
\end{array}$ & $\begin{array}{c}.454^{* *} \\
.000 \\
60 \\
\end{array}$ & $\begin{array}{c}.511^{* *} \\
.000 \\
60 \\
\end{array}$ & $\begin{array}{l}.130 \\
.322 \\
60 \\
\end{array}$ & $\begin{array}{l}.504^{* *} \\
.000 \\
60 \\
\end{array}$ & $\begin{array}{l}.051 \\
.701 \\
60 \\
\end{array}$ & $\begin{array}{c}.311^{*} \\
.015 \\
60 \\
\end{array}$ & $\begin{array}{c}-.015 \\
.911 \\
60 \\
\end{array}$ \\
\hline $\begin{array}{l}\text { Time Delivery Of SHAHAB } \\
\text { KHODRO's Buses }\end{array}$ & $\begin{array}{l}\text { Pearson Correlation } \\
\text { Sig. (2-tailed) } \\
\mathrm{N}\end{array}$ & $\begin{array}{c}.102 \\
.438 \\
60\end{array}$ & $\begin{array}{c}.035 \\
.788 \\
60\end{array}$ & $\begin{array}{l}.438^{* *} \\
.000 \\
60\end{array}$ & $\begin{array}{l}.195 \\
.135 \\
60\end{array}$ & 60 & $\begin{array}{l}.422^{* *} \\
.001 \\
60\end{array}$ & $\begin{array}{c}.130 \\
.322 \\
60\end{array}$ & $\begin{array}{l}.479^{* *} \\
.000 \\
60\end{array}$ & $\begin{array}{c}.299^{*} \\
.020 \\
60\end{array}$ & $\begin{array}{l}.406^{* *} \\
.001 \\
60\end{array}$ & $\begin{array}{l}.546^{* *} \\
.000 \\
60\end{array}$ & $\begin{array}{l}.184 \\
.159 \\
60\end{array}$ \\
\hline Easy Installation Of Buses & $\begin{array}{l}\text { Pearson Correlation } \\
\text { Sig. (2-tailed) } \\
\mathrm{N}\end{array}$ & $\begin{array}{l}.443^{* * *} \\
.000 \\
60\end{array}$ & $\begin{array}{c}.118 \\
.368 \\
60\end{array}$ & $\begin{array}{l}.541^{* *} \\
.000 \\
60\end{array}$ & $\begin{array}{l}.454^{* *} \\
.000 \\
60\end{array}$ & $\begin{array}{l}.422^{* *} \\
.001 \\
60\end{array}$ & 60 & $\begin{array}{c}.491^{* *} \\
.000 \\
60\end{array}$ & $\begin{array}{l}.249 \\
.055 \\
60\end{array}$ & $\begin{array}{l}.470^{* *} \\
.000 \\
60\end{array}$ & $\begin{array}{l}.331^{* *} \\
.010 \\
60\end{array}$ & $\begin{array}{c}.683^{* *} \\
.000 \\
60\end{array}$ & $\begin{array}{c}.050 \\
.702 \\
60\end{array}$ \\
\hline $\begin{array}{l}\text { Flexibility Of SHAHAB } \\
\text { KHODRO In Sense Of Customer } \\
\text { Support, Spare Parts }\end{array}$ & $\begin{array}{l}\text { Pearson Correlation } \\
\text { Sig. (2-tailed) } \\
\mathrm{N}\end{array}$ & $\begin{array}{c}.672^{* * *} \\
.000 \\
60\end{array}$ & $\begin{array}{c}.445^{* *} \\
.000 \\
60\end{array}$ & $\begin{array}{l}.484^{* *} \\
.000 \\
60\end{array}$ & $\begin{array}{l}.511^{* *} \\
.000 \\
60\end{array}$ & $\begin{array}{l}.130 \\
.322 \\
60\end{array}$ & $\begin{array}{l}.491^{* *} \\
.000 \\
60\end{array}$ & 60 & $\begin{array}{r}-.017 \\
.897 \\
60\end{array}$ & $\begin{array}{l}.682^{* *} \\
.000 \\
60\end{array}$ & $\begin{array}{l}.272^{*} \\
.036 \\
60\end{array}$ & $\begin{array}{c}.256^{*} \\
.049 \\
60\end{array}$ & $\begin{array}{c}-.101 \\
.444 \\
60\end{array}$ \\
\hline $\begin{array}{l}\text { Price Of SHAHAB KHODRO's } \\
\text { Buses Compared With } \\
\text { Performance }\end{array}$ & $\begin{array}{l}\text { Pearson Correlation } \\
\text { Sig. (2-tailed) } \\
\mathrm{N}\end{array}$ & $\begin{array}{c}-.056 \\
.672 \\
60 \\
\end{array}$ & $\begin{array}{c}.067 \\
.610 \\
60 \\
\end{array}$ & $\begin{array}{c}.314^{*} \\
.014 \\
60 \\
\end{array}$ & $\begin{array}{l}.130 \\
.322 \\
60 \\
\end{array}$ & $\begin{array}{c}.479^{* *} \\
.000 \\
60 \\
\end{array}$ & $\begin{array}{c}.249 \\
.055 \\
60 \\
\end{array}$ & $\begin{array}{c}-.017 \\
.897 \\
60 \\
\end{array}$ & 60 & $\begin{array}{l}.035 \\
.788 \\
60 \\
\end{array}$ & $\begin{array}{l}.245 \\
.060 \\
60 \\
\end{array}$ & $\begin{array}{c}.499^{* *} \\
.000 \\
60 \\
\end{array}$ & $\begin{array}{l}.154 \\
.239 \\
60 \\
\end{array}$ \\
\hline $\begin{array}{l}\text { Marketing Of SHAHAB } \\
\text { KHODRO For Introducing Buses }\end{array}$ & $\begin{array}{l}\text { Pearson Correlation } \\
\text { Sig. (2-tailed) } \\
\mathrm{N}\end{array}$ & $\begin{array}{c}.585^{* *} \\
.000 \\
60\end{array}$ & $\begin{array}{c}.501^{* *} \\
.000 \\
60\end{array}$ & $\begin{array}{l}.394^{* *} \\
.002 \\
60\end{array}$ & $\begin{array}{c}.504^{* *} \\
.000 \\
60\end{array}$ & $\begin{array}{c}.299^{*} \\
.020 \\
60\end{array}$ & $\begin{array}{l}.470^{* *} \\
.000 \\
60\end{array}$ & $\begin{array}{l}.682^{* *} \\
.000 \\
60\end{array}$ & $\begin{array}{l}.035 \\
.788 \\
60 \\
\end{array}$ & 60 & $\begin{array}{c}.338^{* *} \\
.008 \\
60\end{array}$ & $\begin{array}{l}.246 \\
.059 \\
60\end{array}$ & $\begin{array}{c}-.210 \\
.108 \\
60\end{array}$ \\
\hline $\begin{array}{l}\text { Geographical Distance To } \\
\text { SHAHAB KHODRO's Vendors }\end{array}$ & $\begin{array}{l}\text { Pearson Correlation } \\
\text { Sig. (2-tailed) } \\
\text { N }\end{array}$ & $\begin{array}{c}.107 \\
.416 \\
60 \\
\end{array}$ & $\begin{array}{c}.033 \\
.802 \\
60 \\
\end{array}$ & $\begin{array}{c}.284^{*} \\
.028 \\
60 \\
\end{array}$ & $\begin{array}{c}.051 \\
.701 \\
60 \\
\end{array}$ & $\begin{array}{c}.406^{* *} \\
.001 \\
60 \\
\end{array}$ & $\begin{array}{l}.331^{* *} \\
.010 \\
60 \\
\end{array}$ & $\begin{array}{c}.272^{*} \\
.036 \\
60 \\
\end{array}$ & $\begin{array}{l}.245 \\
.060 \\
60 \\
\end{array}$ & $\begin{array}{l}.338^{* *} \\
.008 \\
60 \\
\end{array}$ & 60 & $\begin{array}{l}.376^{* *} \\
.003 \\
60 \\
\end{array}$ & $\begin{array}{c}.097 \\
.460 \\
60 \\
\end{array}$ \\
\hline $\begin{array}{l}\text { Clear And Easy Technical } \\
\text { Documentations }\end{array}$ & $\begin{array}{l}\text { Pearson Correlation } \\
\text { Sig. (2-tailed) } \\
\mathrm{N}\end{array}$ & $\begin{array}{c}.142 \\
.279 \\
60\end{array}$ & $\begin{array}{c}-.060 \\
.647 \\
60\end{array}$ & $\begin{array}{l}.627^{* *} \\
.000 \\
60\end{array}$ & $\begin{array}{c}.311^{*} \\
.015 \\
60\end{array}$ & $\begin{array}{l}.546^{* *} \\
.000 \\
60\end{array}$ & $\begin{array}{l}.683^{* *} \\
.000 \\
60\end{array}$ & $\begin{array}{c}.256^{*} \\
.049 \\
60\end{array}$ & $\begin{array}{l}.499^{* *} \\
.000 \\
60\end{array}$ & $\begin{array}{l}.246 \\
.059 \\
60\end{array}$ & $\begin{array}{l}.376^{* *} \\
.003 \\
60\end{array}$ & 60 & $\begin{array}{l}.338^{* *} \\
.008 \\
60\end{array}$ \\
\hline $\begin{array}{l}\text { An Earlier Relation With A } \\
\text { Supplier Increase The } \\
\text { Profitability Of Future } \\
\text { Cooperation }\end{array}$ & $\begin{array}{l}\text { Pearson Correlation } \\
\text { Sig. (2-tailed) }\end{array}$ & $\begin{array}{l}-.157 \\
.232\end{array}$ & $\begin{array}{l}-.147 \\
.263\end{array}$ & $\begin{array}{l}.189 \\
.147\end{array}$ & $\begin{array}{r}-.015 \\
.911\end{array}$ & $\begin{array}{l}.184 \\
.159\end{array}$ & $\begin{array}{l}.050 \\
.702\end{array}$ & $\begin{array}{r}-.101 \\
.444\end{array}$ & $\begin{array}{l}.154 \\
.239\end{array}$ & $\begin{array}{l}-.210 \\
.108\end{array}$ & $\begin{array}{l}.097 \\
.460\end{array}$ & $\begin{array}{l}.338^{* *} \\
.008\end{array}$ & 60 \\
\hline
\end{tabular}

**. Correlation is significant at the 0.01 level (2-tailed).

*. Correlation is significant at the 0.05 level (2-tailed). 
Table 15. The most influential elements in choosing SHAHAB KHODRO by customers

\begin{tabular}{|c|c|c|c|c|c|c|c|c|c|c|c|c|c|c|}
\hline Customers/Attributes & 总 & 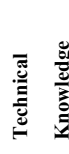 & 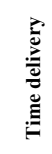 & 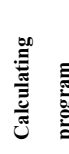 & 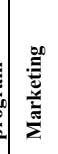 & 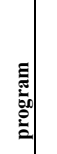 & $\frac{\partial}{\partial}$ & 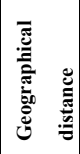 & 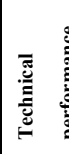 & है. & 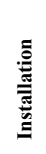 & 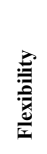 & 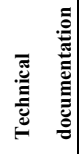 & 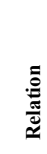 \\
\hline 1 & 2 & 1 & & & & & & & & & & & & 3 \\
\hline 2 & 1 & & & & 2 & & & & & & & & & \\
\hline 3 & 2 & & & & 1 & & & & & & & & 3 & \\
\hline 4 & & 3 & & & 1 & & 2 & & & & & & & \\
\hline 5 & 3 & & & & & & & & 1 & & 2 & & & \\
\hline \multicolumn{15}{|l|}{6} \\
\hline 7 & 3 & 2 & & & & & & & & & & & 1 & \\
\hline 8 & 3 & 2 & & & & & 1 & & & & & & & \\
\hline 9 & 3 & 2 & & & & & & 1 & & & & & & \\
\hline 10 & 1 & & 2 & & & & 3 & & & & & & & \\
\hline 11 & 3 & 2 & & & & & & & & & & 1 & & \\
\hline 12 & 2 & 1 & & & & & & & & & & 3 & & \\
\hline \multicolumn{15}{|l|}{13} \\
\hline 14 & 1 & & 2 & & & & 3 & & & & & & & \\
\hline 15 & 1 & & & & & & 3 & & & & & & 2 & \\
\hline 16 & 1 & & & & & & 3 & & & 2 & & & & \\
\hline \multicolumn{15}{|l|}{17} \\
\hline 18 & 1 & 2 & . & & & & 3 & & & . & & & & \\
\hline 19 & 3 & 2 & & & & & 1 & & & & & & & \\
\hline 20 & 2 & 3 & & & & & 1 & & & & & & 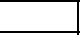 & \\
\hline 21 & 3 & & & & & & & & & 2 & & & 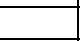 & 1 \\
\hline 22 & 1 & 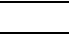 & 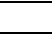 & & 2 & & 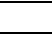 & & & & & & 3 & \\
\hline 23 & 1 & & & & & & 3 & & & & & & 2 & \\
\hline 24 & 2 & & & & & & 3 & & 1 & & & & & \\
\hline 25 & & 3 & . & & 2 & & & & & & & & 1 & \\
\hline 26 & & & 2 & & 3 & & & & 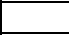 & & & & 1 & \\
\hline 27 & 3 & 1 & & & & & & & & & & & 2 & \\
\hline 28 & & 2 & & & & & & & & & & & 3 & \\
\hline 29 & . & & 2 & & 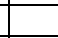 & & & & 1 & & & & 3 & \\
\hline 30 & & & 2 & & 1 & & & & & & & & 3 & \\
\hline \multicolumn{15}{|l|}{31} \\
\hline 32 & 1 & 2 & & & & & & & & & & & 3 & \\
\hline 33 & & 2 & 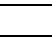 & & 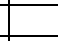 & & 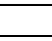 & & 3 & 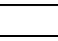 & 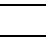 & & 1 & \\
\hline \multicolumn{15}{|l|}{34} \\
\hline \multicolumn{15}{|l|}{35} \\
\hline 36 & & & 1 & & & & & & & & 2 & & 3 & \\
\hline 37 & & & 1 & & & & & & & 3 & 2 & & & \\
\hline 38 & & & 1 & & 2 & & & & & 3 & & & & \\
\hline 39 & 1 & 2 & & & & & & & 3 & & & & & \\
\hline 40 & 1 & & & & & & & 3 & & 2 & & & & \\
\hline 41 & 1 & & & & & & & & 2 & & & & 3 & \\
\hline 42 & & 1 & & & & & & & 3 & & & & 2 & \\
\hline 43 & & 1 & & & 3 & & & & 2 & & & & 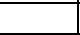 & \\
\hline \multicolumn{15}{|l|}{44} \\
\hline 45 & 1 & & & & & & 2 & & & & & & 3 & \\
\hline 46 & & 2 & 1 & & & & & & & & 3 & & & \\
\hline 47 & & & & & & & & & & & & & 1 & 3 \\
\hline 48 & 2 & & & & & & & & & & & & & \\
\hline \multicolumn{15}{|l|}{49} \\
\hline 50 & & & & & & & 2 & 3 & 1 & & & & & \\
\hline \multicolumn{15}{|l|}{51} \\
\hline 52 & 3 & & & 2 & & & & & & & & & & 1 \\
\hline 53 & 2 & & & & & & & 3 & & & & & & 1 \\
\hline 54 & & & & 1 & & & & & & 2 & & & 3 & \\
\hline 55 & & & & 3 & & & & & & 2 & & & & 1 \\
\hline 56 & & & 3 & 2 & & & & & & 3 & & & & \\
\hline 57 & & & & & & & & & & & & & & \\
\hline 58 & & 1 & & & & & & & & 2 & & & & 3 \\
\hline 59 & & 1 & & & & & & 2 & & & & & & 3 \\
\hline 60 & & & 2 & 1 & & & & & & & & & & 3 \\
\hline Choosing Choice number 1 & 13 & 7 & 4 & 2 & 3 & & 3 & 1 & 4 & 0 & 0 & 1 & 5 & 4 \\
\hline Choosing Choice number 2 & 7 & 11 & 6 & 2 & 4 & & 3 & 1 & 2 & 6 & 3 & 0 & 4 & $\mathbf{0}$ \\
\hline Choosing Choice number 3 & 9 & 3 & 1 & 1 & 2 & & 7 & 3 & 3 & 3 & 1 & 1 & 10 & 5 \\
\hline The score of each element & 62 & 46 & 25 & 11 & 19 & & 22 & 8 & 19 & 15 & 7 & 4 & 33 & 17 \\
\hline
\end{tabular}


Table 16. The decision makers

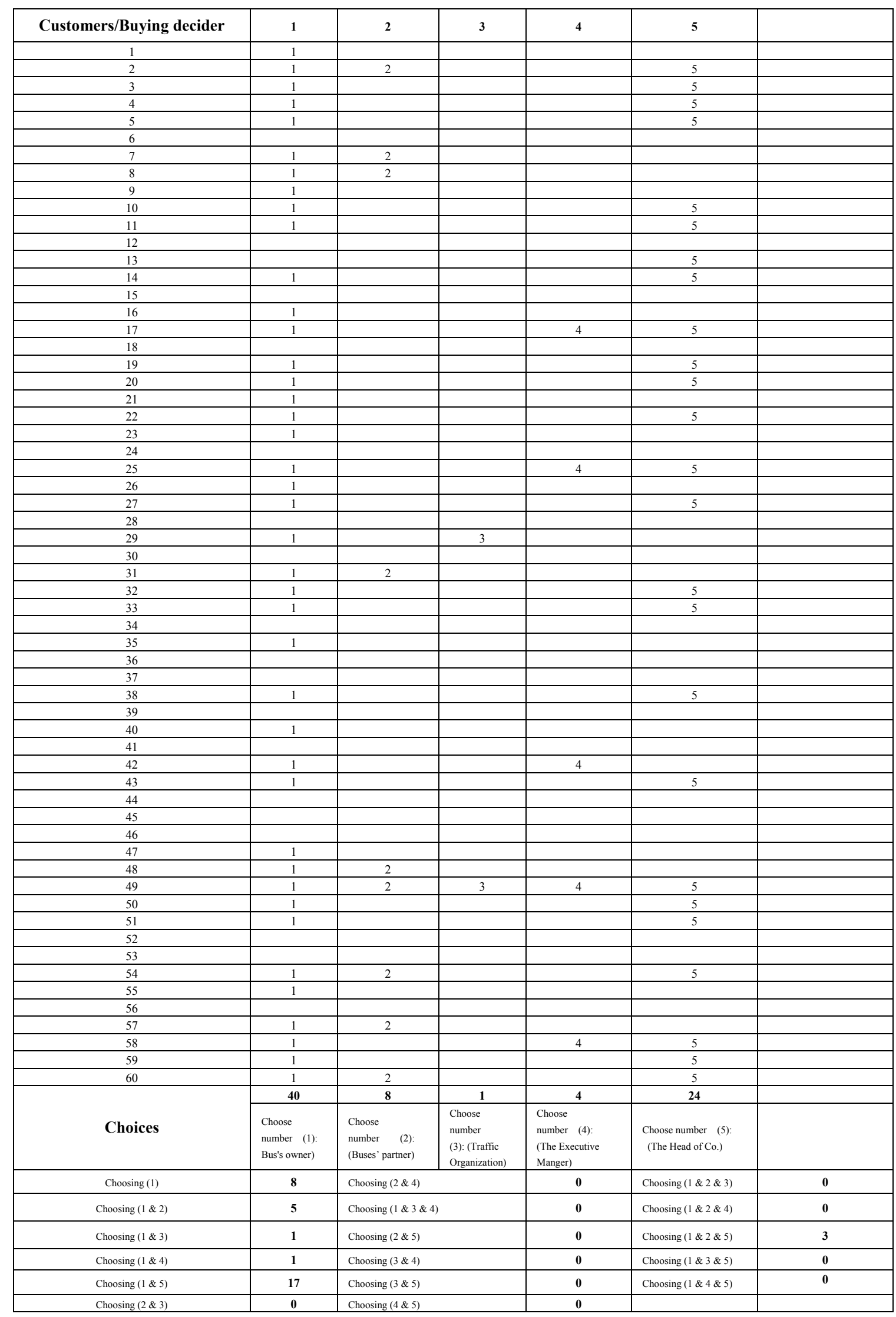




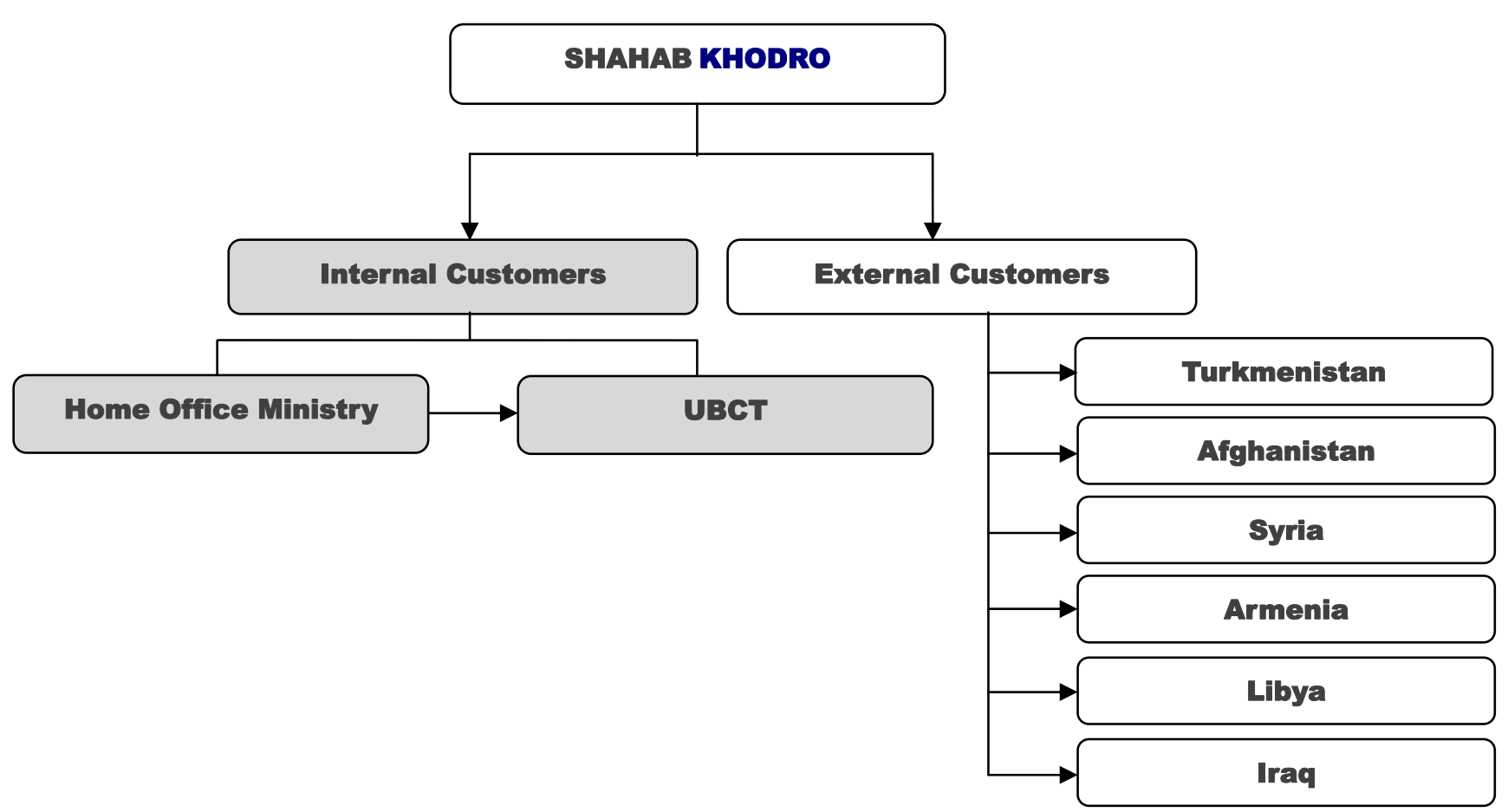

Figure 1. The relationship of SHAHAB KHODRO with its customer (Source: Authors' own Construction)

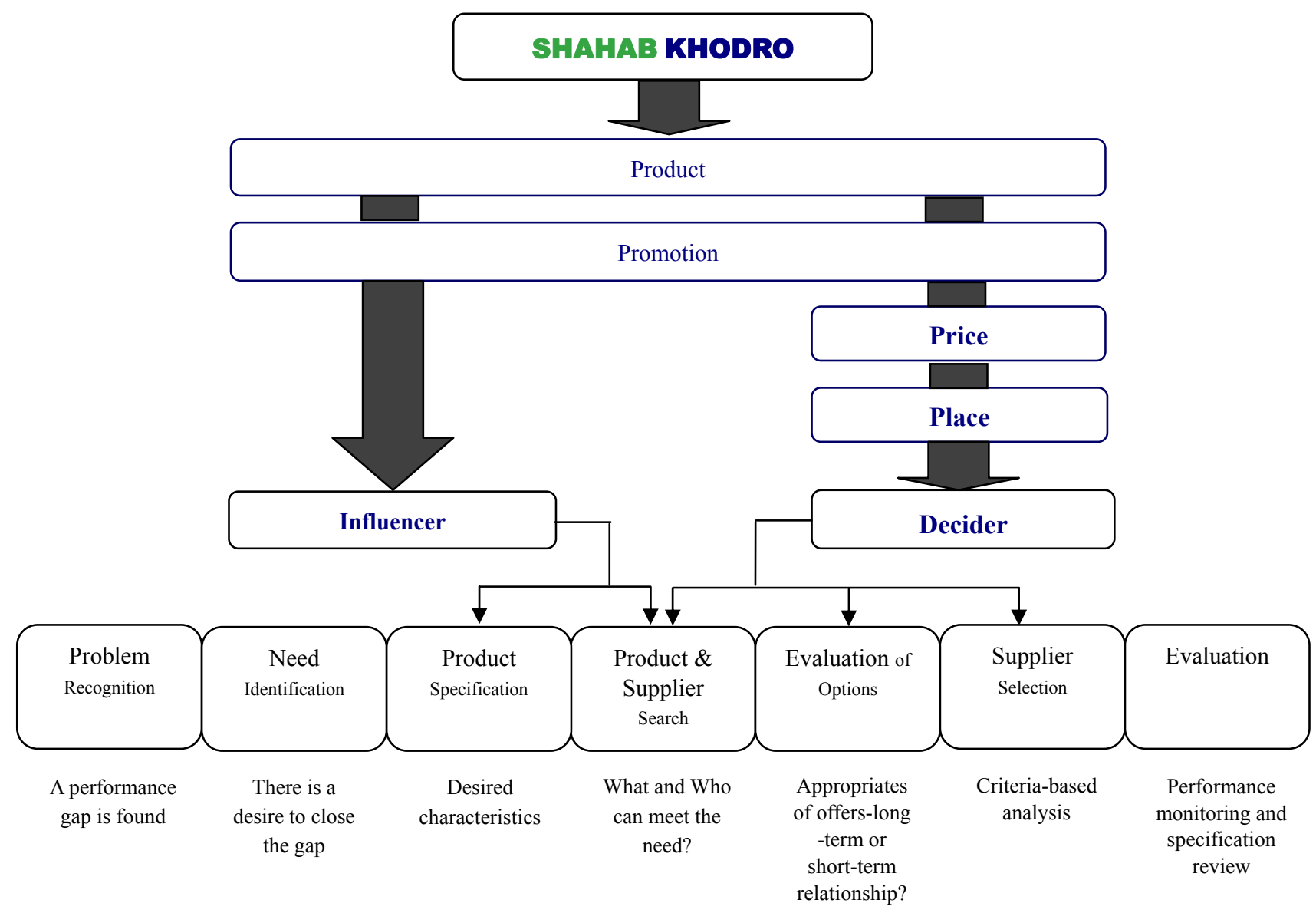

Figure 2. A description of what elements SHAHAB KHODRO should focus on in their marketing program (source: What influences B2B buying behavior, Berggren Jennie, Lejon Elina, Wahlund Linda-Marie, 2005) 


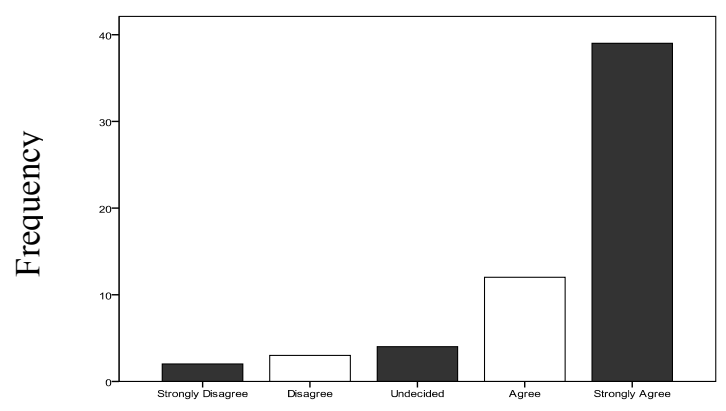

Figure 3. The importance of good earlier relations

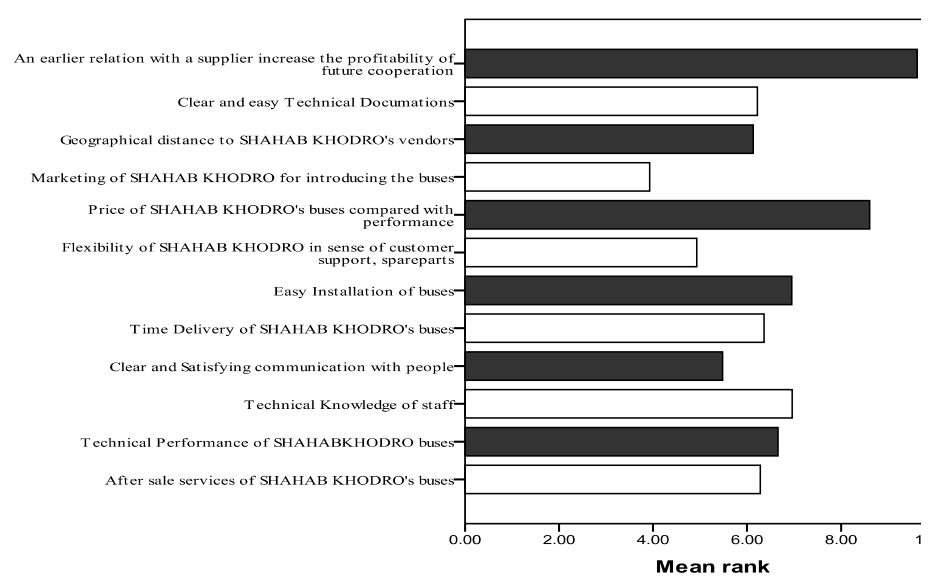

Figure 4 . The elements ranking by the customers 


\section{- Appendix A}

Table $\mathrm{A}_{1}$. A brief literature

\begin{tabular}{|c|c|c|c|}
\hline Scholars & Topics & What they said & Year \\
\hline (Saxe \& Weitz, 1982) & \multirow{5}{*}{$\begin{array}{l}\text { Value creation in business } \\
\text { to business environment }\end{array}$} & $\begin{array}{l}\text { Declare that helping customers make satisfactory purchase } \\
\text { decisions is emphasize of customer-oriented selling strategy }\end{array}$ & 1982 \\
\hline (Anderson, 1995) & & $\begin{array}{l}\text { Value is regarded to be the purpose of cooperative } \\
\text { customer-supplier relationships }\end{array}$ & 1995 \\
\hline (Brett, 2000) & & $\begin{array}{l}\text { In business negotiations also Cultural values use to } \\
\text { influence the interests, priorities, and strategies }\end{array}$ & 2000 \\
\hline (Shi, 2001) & & $\begin{array}{l}\text { Cultural values consequently affects an individual's } \\
\text { approach for exchange relationships }\end{array}$ & 2001 \\
\hline (Liu \& Leach, 2001) & & $\begin{array}{l}\text { Most organizational buyers look for long-term relationships } \\
\text { and higher level of contact from salespeople }\end{array}$ & 2001 \\
\hline (Ryding, 2010) & $\begin{array}{l}\text { Creating repurchase in } \\
\text { industrial marketing }\end{array}$ & $\begin{array}{l}\text { When a customer's achieve their expectation and the } \\
\text { customer obtains a good experiment from his/her } \\
\text { relationship with the organization in this situation } \\
\text { Commitment and repurchase will happen }\end{array}$ & 2010 \\
\hline (Morris, et al., 2001) & \multirow{2}{*}{$\begin{array}{l}\text { Sustain relationship with } \\
\text { customers by } \mathrm{CRM}\end{array}$} & $\begin{array}{l}\text { The management of } \mathrm{B} 2 \mathrm{~B} \text { relationships is about deciding } \\
\text { whom the organization wishes to have a relationship with, } \\
\text { then once having the relationship, how to maintain it. }\end{array}$ & 2001 \\
\hline (King \& Burgess, 2007) & & $\begin{array}{l}\text { Some believes that CRM create as an approach toward } \\
\text { sustaining positive relationships with customers, enhance } \\
\text { loyalty in customer and improve customer lifetime value }\end{array}$ & 2007 \\
\hline (Smith \& Taylor, 2002) & \multirow{2}{*}{$\begin{array}{l}\text { Industrial market vs. } \\
\text { consumer market }\end{array}$} & $\begin{array}{l}\text { The uncertainly of rational and emotional decisions not only } \\
\text { affects the buying behavior of consumers, but also the } \\
\text { rational buying behavior of industrial experts }\end{array}$ & \multirow{2}{*}{2002} \\
\hline (Kotler, et al., 2002) & & $\begin{array}{l}\text { The major differences include market structure and } \\
\text { demand, characters of the buying unit, sort of process of } \\
\text { decisions. Industrial markets also concern far fewer but far } \\
\text { larger buyers than the consumer markets }\end{array}$ & \\
\hline (Kotler, et al., 2002) & \multirow[t]{2}{*}{ Task and non-task variables } & $\begin{array}{l}\text { Some factors in present and future economic environment } \\
\text { such as the initially demands level, the economic perspective } \\
\text { and the expense of money strongly influenced industrial } \\
\text { purchasers }\end{array}$ & 2002 \\
\hline (Jennie, et al., 2005 ) & & $\begin{array}{l}\text { Task variables or rational variables influence on purchasing } \\
\text { decision such as price, quality, delivery etc, that categorize } \\
\text { them into two groups of factors that it include } \\
\text { environmental factors and product and market factors }\end{array}$ & 2005 \\
\hline (Kotler, et al., 2002) & \multirow{4}{*}{ Non-task variables } & $\begin{array}{l}\text { DMU involves many different members who influence on } \\
\text { each other, and it can be taught to realized what kinds of } \\
\text { interpersonal factors and group impact on buying decision }\end{array}$ & 2002 \\
\hline \multirow{3}{*}{ (Jennie, et al., 2005 ) } & & $\begin{array}{l}\text { Non-task variables relate to some factors like } \\
\text { organizational, individual and interpersonal factors }\end{array}$ & \multirow{3}{*}{2005} \\
\hline & & $\begin{array}{l}\text { The interpersonal factors involve the purchasing centre or } \\
\text { the decision making unit (DMU }\end{array}$ & \\
\hline & & $\begin{array}{l}\text { In to the B2B market the mechanism of the DMU is } \\
\text { significant }\end{array}$ & \\
\hline (Smith \& Taylor, 2002) & $\begin{array}{l}\text { Types of purchasing } \\
\text { situation in industrial } \\
\text { marketing }\end{array}$ & $\begin{array}{l}\text { A new task buying situation take place when the firm hasn't } \\
\text { any experience of buying the product or service modified } \\
\text { re-buy situations happen when industrial buyer has earlier } \\
\text { experience about the product or service. However tend to } \\
\text { change product specifications, prices, terms or suppliers. } \\
\text { A straight re-buy situation take place when the firm } \\
\text { frequently purchasing good or services without } \\
\text { modification }\end{array}$ & 2002 \\
\hline
\end{tabular}




\section{- Appendix B}

Please mark the square that you think fits best to You and Your company.

1. The service concerning buses is satisfying when we call SHAHAB KHODR's vendors or technical support.

$\begin{array}{lllll}1 & 2 & 3 & 4 & 5 \\ \begin{array}{l}\text { Do not } \\ \text { agree }\end{array} & & & \begin{array}{l}\text { Totally } \\ \text { agree }\end{array}\end{array}$

2. SHAHAB KHODR's buses have a satisfying technical performance.

$\begin{array}{lllll}1 & 2 & 3 & 4 & 5 \\ \begin{array}{l}\text { Do not } \\ \text { agree }\end{array} & & & \begin{array}{l}\text { Totally } \\ \text { agree }\end{array}\end{array}$

3. The people from SHAHAB KHODR that we are in contact with have enough technical knowledge.

$\begin{array}{lllll}1 & 2 & 3 & 4 & 5 \\ \begin{array}{l}\text { Do not } \\ \text { agree }\end{array} & & & & \begin{array}{l}\text { Totally } \\ \text { agree }\end{array} \\ \square & \square & \square & \square & \square\end{array}$

4. We have a clear and satisfying communication with the people at SHAHAB KHODR that we are in contact with.

$\begin{array}{lllll}1 & 2 & 3 & 4 & 5 \\ \begin{array}{l}\text { Do not } \\ \text { agree }\end{array} & & & & \begin{array}{l}\text { Totally } \\ \text { agree }\end{array} \\ \square & \square & \square & \square & \square\end{array}$

5. The time of delivery of SHAHAB KHODR's buses is reasonable.

$\begin{array}{lllll}1 & 2 & 3 & 4 & 5 \\ \begin{array}{l}\text { Do not } \\ \text { agree }\end{array} & & & & \begin{array}{l}\text { Totally } \\ \text { agree }\end{array}\end{array}$

agree

6. SHAHAB KHODR's buses are easy to install.

$\begin{array}{lllll}1 & 2 & 3 & 4 & 5 \\ \begin{array}{l}\text { Do not } \\ \text { agree }\end{array} & & & & \begin{array}{l}\text { Totally } \\ \text { agree }\end{array}\end{array}$

7. SHAHAB KHODR is flexible, for instance in the sense of customer support, to develop special solutions, spare parts etc.

$\begin{array}{lllll}1 & 2 & 3 & 4 & 5 \\ \begin{array}{l}\text { Do not } \\ \text { agree }\end{array} & & & & \begin{array}{l}\text { Totally } \\ \text { agree }\end{array} \\ \square & \square & \square & \square & \square\end{array}$

8. The prices of SHAHAB KHODR's buses are reasonable relative to their performance.

$\begin{array}{lllll}1 & 2 & 3 & 4 & 5 \\ \begin{array}{l}\text { Do not } \\ \text { agree }\end{array} & & & & \begin{array}{l}\text { Totally } \\ \text { agree }\end{array} \\ \square & \square & \square & \square & \square\end{array}$

9. The time of delivery of SHAHAB KHODR's buses is reasonable.

$\begin{array}{lllll}1 & 2 & 3 & 4 & 5 \\ \begin{array}{l}\text { Do not } \\ \text { agree }\end{array} & & & & \begin{array}{l}\text { Totally } \\ \text { agree }\end{array} \\ \square & \square & \square & \square & \square\end{array}$

10. The geographic distance to SHAHAB KHODR's vendors is satisfying.

$\begin{array}{lllll}1 & 2 & 3 & 4 & 5 \\ \text { Do not } & & & & \begin{array}{l}\text { Totally } \\ \text { agree }\end{array} \\ \square & \square & \square & \square & \square\end{array}$

11. SHAHAB KHODR has a clear and easily used technical documentation.

$\begin{array}{lllll}1 & 2 & 3 & 4 & 5 \\ \begin{array}{l}\text { Do not } \\ \text { agree }\end{array} & & & \text { Totally } \\ \square & \square & \square\end{array}$

12. An earlier good relation with a supplier increases the probability of future cooperation.

$\begin{array}{lllll}1 & 2 & 3 & 4 & 5 \\ \begin{array}{l}\text { Do not } \\ \text { agree }\end{array} & & & & \begin{array}{l}\text { Totally } \\ \text { agree }\end{array} \\ \square & \square & \square & \square & \square\end{array}$


13. Which of the following elements affected you the most when you chose SHAHAB KHODR as a supplier of bus during the last collaboration?

Please rank the three most important elements, where number 1 is the most important one.

Service.

Technical performance.

Technical knowledge.

Communication..

Time of delivery.

Installation.

Flexibility......

Marketing activity.

Technical documentation.

Quality Relationships.

Geographic distance.

14. How likely is it that you would recommend SHAHAB KHODRO to a friend or colleague?(0: Not at all likely, 10: Extremely likely)

0

15. Who is/are involved in a buying decision in your company (what position do these people have)?

16. The foundation year of Your Company:

17. Number of employees:

18. Your position in the company:

19. Type of company (installation engineer or consultant): 